\title{
Pengaruh Kualitas Produk Terhadap Loyalitas Pelanggan
} Kosmetik Wardah di Transmart Bahu Manado

\author{
Riska Asnawi Nyonyie \\ J.A.F. Kalangi \\ Lucky F. Tamengkel \\ Jurusan Ilmu Administrasi, Program Studi Administrasi Bisnis \\ Fakultas Ilmu Sosial dan Politik, Universitas Sam Ratulangi Manado \\ Email : riskanyonyie03@gmail.com
}

\begin{abstract}
This study aims to determine the effect of Product Quality on Customer Loyalty Wardah Cosmetic at Transmart Bahu Manado. This research method uses quantitative method, with sample of 96 respondents who are Wardah product costumers. The sampling techniques in this study are using Purposive Sampling. Data collection techniques in this study were questionnaires. Data analysis method used in this study is a simple regression data analysis method with associative approach to see causal relationship that include validity test, reliability test and simple regression analysis processed using the help of computer program SPSS 25. From the test result can be known statistically, it can be seen clearly that the independent variable Product Quality affects the dependent variable Customer Loyalty. The result of the study show: Based on the calculation results of the determinant coefficient obtained the $R$ square value of 0,725 or 72,5\% which states that there is variable influence Product Quality on the variable Customer Loyalty, while the remaining 24,5\% are influenced by other factors not present in this study. This shows that Product Quality has a significant effect on Customer Loyalty. Where if the Product Quality is getting better, the Customer Loyalty will be higher too.
\end{abstract}

Key words: Product Quality and Customer Loyalty

\section{Pendahuluan}

Di Indonesia menggunakan kosmetik sudah menjadi salah satu hal yang biasa dilakukan oleh para wanita sebelum melakukan aktivitas mereka sehari-hari. Pada era globalisasi saat ini persaingan berbagai produk kometik kecantikan sudah sangat ketat. Oleh karena itu perusahaan harus mengerti apa yang menjadi kebutuhan atau keinginan konsumen. Sebagian wanita menyukai produk kosmetik dengan kualitas yang bagus dengan harga yang terjangkau, ada juga wanita yang rela membeli produk kosmetik dengan harga yang mahal asalkan kualitas dari produk tersebut bagus dan bermerek. Banyak pemasar yang yang menyediakan produk kosmetik dengan kualitas yang bagus dan harga yang terbilang cukup terjangkau, tetapi ada juga pemasar yang menyediakan produk kosmetik bermerek dengan kualitas yang baik tetapi dengan harga yang mahal. 
Persaingan kualitas produk yang begitu sengit yang membuat setiap pemasar berlomba-lomba menyediakan produk yang dapat diterima dan disukai oleh masyarakat sehingga kepuasan didapat setelah menggunakan produk dan akan membuat konsumen melakukan pembelian kembali dimasa yang akan datang. Salah satu perusahaan yang menawarkan produk dengan kualitas yang bagus dan harga yang terjangkau adalah PT. Paragon Technology and Innovation. PT. Paragon Technology and Innovation adalah salah satu perusahaan yang meluncukan produknya dengan tiga merek yaitu Wardah. Semakin banyak produk kosmetik yang ada perusahaan harus mampu membuat atau menciptakan produk yang mampu menarik konsumen dan mampu memberikan kepuasan kepada pemakai kosmetik itu sendiri dari segi kualitas maupun kelengkapan alat- alat kosmetik tersebut. Hal ini yang diterapkan oleh counter wardah yang berada di Transmart Bahu Jln.Wolter Monginsidi Bahu Kota Manado. Untuk membuat kualitas produk menjadi baik dan menimbulkan loyalitas pelanggan para SPG (Seles Promotion Girls) harus dapat mengkomunikasikan produk yang mereka jual (Wardah) dan memberi daya tarik tersendiri bagi pelanggan sehingga menimbulkan minat dan melakukan pembelian kembali, kemudian menjadi pelanggan setia, tetapi ada beberapa keluhan yang datang dari para pengguna produk wardah tentang penggalaman menggunakan produk wardah, ada yang mengatakan setelah menggunakan produk wardah wajah mereka menjadi lebih hitam ada juga yang mengatakan setelah menggunaan lipstick wardah bibir mereka terasa kering dan menjadi kaku. Perusahaan harus mampu menanggulangi masalah ini agar mereka tidak kehilangan banyak konsumen dan pelanggan setia yang dapat menurunkan omset pendapatan dan berpindah ke produk kosmetik lain.

\section{Pengertian Pemasaran}

Pemasaran menyangkut dengan semua kegiatan manusia yang berlangsung dalam hubungannya dengan pasar, dan secara tidak langsung pasar merupakan tempat untuk mewujudkan pertukaran yang potensial seperti penjual harus mencari pembeli, menemukan dan memenuhi kebutuhan mereka, merancang produk yang tepat, harga yang tepat, menyimpan dan mempromosikan produk- produk dengan maksud memuaskan kebutuhan dan keinginan konsumen. Menurut Kotler dan Keller (2011:5) Pengertian Pemasaran adalah Mengidentifikasi dan memenuhi kebutuhan manusia dan sosial. 


\section{Kualitas Produk}

Kualitas Produk menjadi faktor penting yang berpengaruh dalam penciptaan kepuasan pelanggan. Kualitas produk merupakan variabel yang penting yang berhubungan dengan penilaian terhadap produk untuk memenuhi harapan dari pelanggan. Pengertian produk menurut (Kotler dan Keller, 2009) adalah segala sesuatu yang dapat ditawarkan kepada pasar untuk memuaskan suatu keinginan atau kebutuhan termasuk barang, fisik, jasa, pengalaman, acara, orang, tempat, property, organisasi, informasi dan ide. Menurut Kotler dan Amstrong (2001)). Kualitas produk didefinisikan sebagai evaluasi menyeluruh pelanggan atas kebaikan kinerja barang atau jasa (Mowen dan Minor, 2002) kualitas produk adalah karakteristik dari produk dalam kemampuan untuk memenuhi kebutuhankebutuhan yang telah ditentukan dan bersifat laten, sedangkan produk adalah segala sesuatu yang dapat ditawarkan kepasar untuk mendapatkan perhatian, dibeli, digunakan, atau dikonsumsi yang dapat memuaskan keinginan atau kebutuhan. Menurut Kotler and amsrtong (2008) arti dari kualitas produk adalah "the ability of a product to perform its functions, it includes the product's overall durability, precision, ease of operation and repair, and other valued attributes" yang artinya kemampuan sebuah produk dalam memperagakan fungsinya, hal itu termasuk keseluruhan durabilitas, reliabilitas, ketetapan, kemudahan pengoperasian dan reparasi produk juga atribut produk lainnya. Kualitas produk termasuk dalam bauran pemasran 4P yaitu : Product, Price, Promotion and Place,

\section{Dimensi Kualitas Produk}

Menurut Tjiptono dkk. (2008:68) ada delapan dimensi dalam kualitas produk, yaitu sebagai berikut : (1). Kinerja (Performance). (2). Ciri-ciri atau keistimewaan tambahan (Features). (3). Kesesuaian dengan spesifikasi (Conformance to Spesification). (4). Keandalan (Realibility). (5). Daya tahan (Durability). (6). Estetika (Esthetica). (7). Kualitas yang dipersepsikan (Perceived Quality). (8). Dimensi kemudahan perbaikan perbaikan (Serviceability).

\section{Faktor-faktor yang mempengaruhi kualitas produk.}

Menurut assauri (200:123) faktorfaktor yang mempengaruhi kualitas suatu produk yaitu: (1). Fungsi suatu produk. (2). Wujud luar (3). Biaya produk bersangkutan

\section{Loyalitas Pelanggan}

Seorang yang loyal akan menjadi set yang sangat berharga bagi perushaan, 
kepuasan pelanggan merupakan salah satu kunci untuk menciptakan loyalitas pelanggan, karena pelanggan yang puas akan cederung loyal. Menurut Tjiptono (2005) dalam Sangadji, etta dan Sopiah (2013:115) mengemukakan enam indikator yang bisa digunakan untuk mengukur loyalitas yaitu : (1). Pembelian ulang (2). Kebiasaan mengkonsumsi merek (3). Rasa suka yang besar pada merek. (4). Ketetapan pada merek (5). Keyakinan bahwa merek tertentu merek yang terbaik (6). Perekomendasian merek kepada orang lain Loyalitas pelanggan adalah suatu pembelian ulang yang dilakukan oleh seorang pelanggan karena komitmen pada suatu merek atau perusahaan. Definisi lain loyalitas konsumen adalah kesediaan konsumen untuk menggunakan produk perusahaan dalam jangka panjang (Lovelock, et all,2010:76). Menurut Tjiptono, Fendy (2011:485), loyalitas konsumen adalah pembelian ulang suatu merek secara konsisten oleh konsumen.

\section{Dimensi Loyalitas Pelanggan}

Terdapat empat macam dimensi loyalitas konsumen menurut Griffin (2010) yaitu : (1). Rata-rata pembelian ulang (2). Membeli produk dan pelayanan yang sama (3). Mempromosikan produk kepada orang lain (4). Menunjukkan kekebalan akan produk yang dimaksud dalam persaingan.

\section{Karakteristik Loyalitas Pelanggan}

Karakteristik dari pelanggan yang loyal menurut Griffin (2005:31) antara lain: (1). Melakukan pembelian secara teratur. (2). Membeli diluar lini produk atau jasa. (3). Menunjukan kekebalan dari tarikan persaingan tidak terpengaruh oleh tarikan persaingan produk sejenis lainnya. (4) Menolak produk lain. Merekomendasikan kepada orang lain.

\section{Hubungan antara Kualitas Produk dan}

\section{Loyalitas Pelanggan}

Kualitas Produk memiliki hubungan dengan Loyalitas Pelanggan. Kualitas produk adalah karakteristik dari sebuah produk yang diberikan kepada pelanggan. Loyalitas adalah komitmen yang dipegang kuat oleh pelanggan sehingga kembali membeli produk. Jika sebuah perusahaan menawarkan produk dengan kualitas yang baik yang dapat memenuhi kepuasan pelanggannya maka akan mempengaruhi kemugkinan terjadinya pembelian kembali terhadap produk tersebut sehingga terjdilah loyalitas pelanggan terhadap produk tersebut.

\section{Metode Penelitian}

Dalam penelitian yang dilakukan pada salah satu counter wardah yang ada di transmart Manado di Jln. Monginsidi, Bahu, Kota Manado, Sulawesi Utara, 
Indonesia. penulis menggunakan metode penelitian kuantitatif. Populasi dalam penelitian ini adalah pelanggan produk Wardah. Karena jumblah populasi sangat besar dan tidak diketahui berapa jumblahnya sehingga jumblah populasi dalam penelitian ini tidak terhingga.

Untuk menentukan sampel dan populasinya besar dan jumblahnya tidak diketahui, dapat menggunakan rumus menurut Rao Purba (2006) dan hasil yang didapat adalah 96 responden atau sampel. Metode yang digunakan dalam pengumpulan sampel pada penelitian ini adalah metode Non-Probability Sampling dengan menggunakan teknik Purposive Sampling Teknik pengumpulan data yaitu kuesioner dengan dinilai menggunakan skala likert, dan model analisis yang digunakan yaitu analisis regresi sederhana.

\section{Hasil dan Pembahasan}

Berdasarkan hasil pengujian kualitas produk dan loyalitas pelanggan menggunakan SPSS 25 diatas, dapat diketahui beberapa hasil penelitian yang dapat diuraikan sebagai berikut:

Pengaruh Kualitas Produk terhadap Loyalitas Pelanggan

Hasil pengujian Validitas pada variabel Kualitas Produk(X), data diperoleh 8 item yang dinyatakan valid dikarenakan mempunyai nilai $r_{\text {hitung }}>r_{\text {tabel }}$, dan hasil pengujian Validitas pada variabel Loyalitas Pelanggan(Y), data yang diperoleh 5 item yang dinyatakan valid dikarenakan mempunyai nilai $r_{\text {hitung }}>r_{\text {tabel }}$. Sedangkan hasil pengujian reliabilitas menunjukan bahwa variabel kualitas produk diperoleh 0,775 dan variabel loyalitas pelanggan diperoleh 0,812 dimana hasil tersebut lebih besar dari (>) 0,6 maka data yang di uji dinyatakan reliabilitas atau data ini dapat dipercaya karena mampu memberikan hasil yang konsisten.

Dari persamaan regresi linear sederhana diperoleh $\mathrm{Y}=3.098+0,685 \mathrm{X}$. Dari persamaan tersebut dapat dijelaskan bahwa nilai kostanta sebesar 3.098 yang menyatakan bahwa jika nilai kualitas produk meningkat sebesar 3.098 maka loyalitas pelanggan akan bernilai sebesar 3.098. nilai koefisien regresi bernilai positif yaitu sebesar 0,685 yang artinya kualitas produk wardah sudah baik sehingga meningkatkan loyalitas pelanggan terhadap produk wardah. Berdasarkan perhitungan koefisien determinan (R2) memperoleh nilai $\mathrm{R}$ square sebesar 0,725 atau $72,5 \%$ yang menyatakan terdapat pengaruh variabel kualitas produk terhadap variabel loyalitas pelanggan, sedangkan sisanya $24,5 \%$ dipengaruhi oleh faktor lain yang tidak ada dipenelitian ini. Selanjutnya berdasarkan hasil analisis menunjukanhasil uji-t diperoleh nilai signifikansi sebesar 
0,000 nilai sig uji-t lebih $\operatorname{kecil}(<)$ dari 0,05 sehingga dapat disimpulkan bahwa variabel kualitas pelayanan (X) berpengaruh terhadap variabel loyalitas pelanggan (Y). berdasarkan nilai $\mathrm{t}$ diketahui nilai $t_{\text {hitung }}$ sebesar 15.740>t $t_{\text {tabel }} 1.986$ sehingga dapat disimpulkan bahwa variabel kualitas produk berpengaruh terhadap loyalitas pelanggan. Hal ini sesuai mendukung penelitian Siti Fauzi'ah (2014) bahwa Kualitas Produk Berpengaruh positif dan signifikan terhadap Loyalitas pelanggan thitung lebih besar dari t-tabel yaitu $t_{\text {hitung }}$ sebesar 15.740> $t_{\text {tabel }}$ sebesar 1.986, dengan tingkat signifikan sebesar 0,000 < 0,05 .

Penelitian ini didukung oleh penelitian sebelumnya yang dilakukan oleh Siti Fauzi'ah (2014) yang menunjukan bahwa Kualitas Produk Berpengaruh positif dan signifikan terhadap Loyalitas Pelanggan dan Penelitian terdahulu dari Arzia Rahma Minawati (2017) yang menunjukan bahwa Kualitas Produk Berpengaruh Terhadap Loyalitas Pelanggan.

\section{Simpulan}

Berdasarkan hasil penelitian maka dapat ditarik simpulan sebagai berikut: (1). Dari hasil penelitian terdapat pengaruh yang terbilang cukup kuat yang menyatakan ada pengaruh variabel kualitas produk terhadap variabel loyalitas pelanggan, sedangkan sisanya dipengaruhi oleh faktor lain yang tidak ada dipenelitian ini. Ini merupakan nilai pengaruh yang cukup besar atau termasuk kategori kuat itu membuktikan bahwa kualitas produk wardah sudah sangat baik dan terpercaya dari segi kinerja produk, fitur produk, kesesuaiaan dan spesifikasi, keandalan, ketahanan/daya tahan, estetika/daya tarik dan kualitas yang dipersipkan dari produk tersebut. untuk itu diharapkan perusahaan harus terus meningkatkan kualitas produk dan terus berinovasi menciptakan produkproduk yang lebih menarik yang dapat disukai oleh pelanggan dengan kualitas yang lebih baik lagi sehingga dapat meningkatkan loyalitas pelanggan terhadap produk wardah, semakin baik kualitas suatu produk maka semakin meningkat juga loyalitas pelanggan sedangan untuk sisahnya mungkin dipengaruh faktor lain mugkin dari faktor pelayanannya atau harga yang harus diperhatikan juga oleh perusahaan agar loyalitas pelanggan dari produk wardah terus meningkat dan semakin baik dimata pelanggan, dan disarankan untuk peneliti selanjutnya diharapkan untuk menambah kedua variabel tersebut yaitu variabel harga dan pelayanan dalam penelitian (2). Berdasarkan hasil penelitian maka dapat 
diambil kesimpulan bahwa Kualitas Produk Berpengaruh terhadap Loyalitas Pelanggan karena memiliki nilai yang signifikan yang berarti ada pengaruh. Kualitas produk dan loyalitas pelanggan memiliki hubungan yang positif, dengan artian semakin baik kualitas produk wardah semakin meningkat juga loyalitas pelanggan oleh karena itu produk wardah harus terus meningkatkan kualitasnya dan terus berkembang dalam mencapai loyalitas pelanggan.

\section{Referensi}

Kotler dan Keller (2011) dalam buku Marketing Management edisi 13 Pengertian Pemasaran.

Kotler dan Keller. (2009). Manajemen Pemasaran. Jakarta: Erlangga.

Kotler dan Amstrong (2001) Prinsipprinsip pemasaran. Penerbit Erlangga, Jakarta

Kotler and Armstrong. (2008) PrinsipPrinsip Pemasaran. Terjemahan damos sihombing. Principles of marketing. 1999. Jakarta: Erlanga.

C Mowen, John. Michael Minor. (2002) Perilaku konsumen. Jakarta Erlangga,

Wehelmina Rumawas, Sandra Asaloe, Gahensya Keloay (2019) Pengaruh Kualitas Produk, harga, dan Kualitas Pelayanan Terhadap Kepuasan Konsumen Pada Rumah Makan Dabu-dabu Iris Fresh Wenang Manado, Vol 8, (No 2, 2019)

Tjiptono , fandy (2011) Pemasaran . Bayumedia Publishing. Yogyakarta
Tjiptono, Fandy, dkk. (2008). Pemasaran Strategik.Yogyakarta : CV. Andi Offset.

Assauri, sofjan. (2001), manajemen produksi dan operasi. fakultas ekonomi universitas Indonesia, Jakarta.

Sangadji, Etta., dan Sopiah. (2013). Perilaku Konsumen. Yogyakarta : CV. Andi Offset.

Lovelock, Christopher, Joachen Wirtz dan Jacky Mussry. (2010). Pemasaran Jasa : Manusia, Teknologi, Strategi. Perspektif Indonesia. Erlangga. Jakarta.

Griffin, Jill. (2010). Customer loyality. Jakarta : penerbit Erlangga

Griffin, Jill. (2005). Coustumer loyality: Menumbuhkan dan mempertahankan kesetiaan pelanggan. Ahli Bahasa Dr. Dwi Kartini Yahya. Jakarta: Erlangga.

Rao Purba, (2006), Measuring Consumer Perception Through Factor Analysis, The Asian Manager (February-March). 